\title{
ZNAMIONA REALIZMU W KONCEPCJI PEDAGOGICZNEJ EDMUNDA BOJANOWSKIEGO ORAZ W PODSTAWACH PROCESU JEJ ZMIAN ADAPTACYJNYCH I ZACHOWANIA TOŻSAMOŚCI
}

Signs of realism in the pedagogical concept of Edmund Bojanowski and in the fundamentals of the process of its adaptive changes and the preservation of identity

S u m m a ry: Opening orphanages, E. Bojanowski created and perfected his pedagogical concept of education. He shaped its philosophical base in terms of realism, which is only possible in a context that is consistent with a factual reading of the world in which people and things exist. He based his thinking on philosophical anthropology, the Bible, and the Church's teachings, which indicated that man is a unity of body and soul, a person, a child of God. This integral and realistic conception of man resulted in the need for his integral development and education. Bojanowski created a system of early education that takes into account the achievements, in thought and practice, of the Church in education, culture, history and tradition, as well as the specificity of the natural environment, the overall factors influencing the child's upbringing and the organization of institutions. Fidelity to accepted assumptions still ensures the continuation and implementation of adaptive changes while maintaining the identity of the concept and the reconstruction of his integral pedagogy in relation to realistic Thomistic philosophy.

Keywords: Edmund Bojanowski, realism, person, religion, anthropology, integral education, pedagogical concept, identity

\section{Wstęp}

Koncepcja pedagogiczna Edmunda Bojanowskiego (1814-1871) powstała w XIX wieku i stanowi podstawę integralnej pedagogiki przedszkolnej¹. Jej rekonstrukcji

1 Koncepcja integralnej pedagogiki przedszkolnej została opracowana na podstawie zawartego w materiałach źródłowych schematu systemu wychowania stworzonego przez E. Bojanowskiego, który uwzględnia szeroki kontekst jego podstaw oraz wymiaru organizacyjnego i funkcjonalnego. Całościowe ujęcie integralnej pedagogiki przedszkolnej zostało zawarte w publikacji: Maria Opiela, Integralna pedagogika przedszkolna wsystemie wychowania Edmunda Bojanowskiego. Kontynuacja izmiana (Lublin: Wydawnictwo KUL 2013). 
dokonano na podstawie analizy materiałów źródłowych, jakimi są rękopisy notatek E. Bojanowskiego ${ }^{2} \mathrm{w}$ duchu kontynuacji zawartych $\mathrm{w}$ nich jej pierwotnych założeń oraz w kontekście współczesnej teorii i praktyki pedagogicznej.

Przyjęcie przez Bojanowskiego systemowych rozwiązań wymagało odczytania ich na nowo, by rozpoznać, co stanowi istotę elastyczności, otwartości i aktualności jego koncepcji wychowania. Analiza dokumentów oraz procesu przemian działalności Służebniczek w kontekście społeczno-kulturowych uwarunkowań pozwoliła zbadać i opisać wzór tej działalności oraz prawidłowości zmian adaptacyjnych przy jednoczesnym zachowaniu ciągłości. Wyodrębnione procesy ciągłości oraz zmiany działalności opiekuńczo-wychowawczej realizowane w różnych kontekstach czasu i miejsca, zjawisk społecznych, politycznych, a także kulturowych wskazały na istotne elementy koncepcji wychowania i jej podstaw. Filozoficzno-religijne odniesienia, wykorzystanie dorobku myśli pedagogicznej, uwarunkowania społeczno-kulturowe oraz tradycja wychowawcza Kościoła stanowiły nie tylko kontekst tworzenia wizji wczesnej edukacji, ale także kontynuacji i jej adaptacyjnych zmian przez Służebniczki³. W samej koncepcji, procesie jej tworzenia i twórczej realizacji od połowy XIX wieku do chwili obecnej odnajdujemy znamiona realizmu, których wskazanie jest celem niniejszego artykułu.

Istotne prawdy o człowieku i wychowaniu Bojanowski poznawał w perspektywie religijno-filozoficznej, której celem jest właściwe rozumienie oraz wyjaśnianie rzeczywistości. Wierność Biblii, Tradycji i konsekwencja w odniesieniu do nauczania Kościoła sprawiła, że na etapie tworzenia koncepcji uniknął on pułapki rozmycia fundamentu i dał jej mocne podstawy, chroniąc przed sekularyzacją w przyszłości. Stanowiły ją integralna, realistyczna koncepcja człowieka oraz wypracowane przez wieki formy edukacji i jej organizacji ujmowane całościowo, systemowo. W tym samym kontekście nadal rozwija się działalność wychowawcza Służebniczek, zachowując swą tożsamość, wyrażającą się $\mathrm{w}$ wierności przyjętym podstawom antropologicznym i wynikającym z nich implikacjom pedagogicznym. Tożsamość koncepcji pedagogicznej E. Bojanowskiego i działalności wychowawczej prowadzonej przez Służebniczki polega na respektowaniu chrześcijańskiego systemu wartości oraz wychowaniu dzieci w tym duchu, zgodnie z nauczaniem i tradycją Kościoła.

\section{Religijno-filozoficzne podstawy koncepcji wczesnego wychowania w ujęciu E. Bojanowskiego}

Uznając religię i filozofię za „najważniejsze uniwersalne sfery”, Bojanowski poszukiwał w nich prawdy o człowieku, jego życiu oraz rozwoju, prawdy nadającej mu sens oraz uniwersalnych celów i zasad wychowania. Miał świadomość jak ważne jest, by koncepcja wychowania opierała się na jasno sformułowanych założeniach, od

\footnotetext{
${ }^{2}$ Archiwum Główne Służebniczek Dębickich w Dębicy (AGSD), Notatki Edmunda Bojanowskiego, (B).

${ }^{3}$ Prowadzona analiza socjologiczno-pedagogiczna i wnioski z badań zostały przedstawione w publikacji: Maria Opiela, Dynamika przemian działalności opiekuńczo - wychowawczej Sióstr Stużebniczek BDNP w ochronkach (Dębica: SBDNP 2011).

${ }^{4}$ Por. AGSD, B-h-1, k. 19r.
} 
których zależą cele, metody, środki i sposób traktowania wychowanka5. Te istotne elementy wychowania wich teoretycznym oraz praktycznym wymiarze wynikają z przyjętej koncepcji człowieka i jego działania. Stąd jej podstawą jest adekwatna antropologia, która stara się zrozumieć oraz tłumaczyć człowieka w tym, co istotnie ludzkie, a także etyka - która ukazuje wizję jego działania moralnego ${ }^{6}$.

Nie jest zatem bez znaczenia, jaką w wychowaniu przyjmie się antropologię i etykę, by we właściwy sposób wprowadzać człowieka w poznawanie, rozumienie oraz urzeczywistnianie takich wartości, jak prawda i dobro. W ten sposób Bojanowski wpisuje się wzałożenia filozoficznego realizmu, uznającego, że nie tylko to rzeczywistość istnieje niezależnie od nas oraz od myślenia oraz teorii, ale i wyprzedza je (realizm ontologiczny). Na płaszczyźnie poznania realizm (realizm poznawczy) stoi na stanowisku, że pierwszoplanowym przedmiotem poznania jest właśnie byt, a następnie świadomość i sam proces poznania. Realizm poznawczy daje więc pierwszeństwo realnym bytom przed procesem ich poznania i uświadomieniem sobie tego procesu7.

Bojanowski, dążąc do sformułowania założeń swej koncepcji, dbał o zgodność poznania z rzeczywistością we wszystkich możliwych wymiarach: przez poznanie zmysłowe, procesy pojęciowania i sądzenia, co jest cechą realizmu poznawczego8. Za pomocą między innymi analogii, analizy hermeneutycznej dążył do racjonalnego rozumienia realnie istniejącej rzeczywistości człowieka i jego wychowania.

Kolejnym przejawem realizmu jest to, iż religijne przekonania Bojanowskiego skierowały jego refleksję ku antropologii chrześcijańskiej, zakorzenionej w myśleniu biblijnym, stojącej na straży podstawowych ludzkich prawd dotyczących godności i wolności człowieka, doczesnego oraz nadprzyrodzonego wymiaru jego życia oraz podobieństwa do Boga. Mimo iż filozofia realistyczna nie szuka w Objawieniu chrześcijańskim przedmiotu poznania ani jego metody, to: „Jeśli filozofowanie oznacza rozważenie całości rzeczywistości pod każdym możliwym sensownie aspektem, to czymś niefilozoficznym byłoby formalne wykluczenie możliwego aspektu [...]. Czymś niefilozoficznym byłoby, jeśli ktoś wierzy w prawdę Objawienia i to, w co wierzy, uważa za prawdziwe, ignorując jednocześnie prawdę Objawienia”. Chociaż nie rozstrzyga ono o tym, jaka ma być właściwa wizja człowieka, to jednak stanowi - obok natury rzeczywistości - istotny punkt odniesienia dla dociekań filozofiii ${ }^{10}$.

\footnotetext{
${ }^{5}$ Zob. Teresa Kukołowicz, „Nowe koncepcje wychowania”. Chrześcijanin w Świecie 4 (1993): 53.

${ }^{6}$ Zob. Opiela, Integralna, 159.

${ }^{7}$ Por. Kazimierz Ajdukiewicz, Zagadnienia i kierunki filozofii (Kęty: Wydawnictwo Antyk 2004), 61-62.

${ }^{8}$ Por. Mieczysław A. Krąpiec, „Realizm poznawczy”, w: Powszechna Encyklopedia Filozofii, red. nauk. Andrzej Maryniarczyk, t.VIII (Lublin: Polskie Towarzystwo Tomasza z Akwinu 2007), 666-669.

${ }^{9}$ Berthold Wald, Filozofia $w$ studium teologii, thum. Joanna Jakuszko (Lublin: PTTA 2006), 66.

${ }^{10}$ Zob. Piotr. S. Mazur, „Mieczysława A. Krąpca OP antropologia integralna”. Człowiek w Kulturze 19 (2007): 158.
} 
U podstaw poszukiwań i refleksji teoretycznych E. Bojanowskiego dotyczących wychowania leży starożytna filozofia człowieka oraz Biblia. Zarówno na gruncie antropologii filozoficznej, jak i antropologii biblijnej, ujmuje się koncepcję człowieka jako osoby i jako dziecka Bożego oraz wynikającą z niej koncepcję moralności. W pismach i poglądach pedagogicznych Bojanowskiego można znaleźć nawiązania do Sokratesa, Platona, Arystotelesa, stoików oraz Ojców i Doktorów Kościoła ze św. Augustynem, św. Ambrożym i św. Grzegorzem na czele ${ }^{11}$. Płaszczyzną lączącą te dwie antropologie: filozoficzną i biblijną (wydaje się, że Bojanowski utożsamia je ze sobą) jest zawarta wnich komplementarna teoria osoby. Antropologia filozoficzna poszukująca odpowiedzi na pytanie o naturę i tożsamość człowieka jako człowieka oraz człowieka jako osoby nie jest nauką teologiczną jak antropologia biblijna, która w Objawieniu poszukuje podpowiedzi na pytanie „Kim jest człowiek?” Z perspektywy dziejów filozofii dostrzec można, iż teoria osoby jest obecna zarówno w greckiej kulturze, jak i filozofii neoplatońskiej ${ }^{12}$, u Ojców Kościoła oraz scholastyków, a także dwudziestowiecznych i współczesnych personalistów. Należy ona zatem tak do filozofii, jak i do nauk społecznych oraz teologii. Wydaje się, że E. Bojanowski świadomie do niej się odniósł, ponieważ stanowi ona syntezę rozumu (starożytność) i wiary (Kościół katolicki), będących podwaliną jego integralnej i realistycznej pedagogiki.

Takie integralne, realistyczne spojrzenie pozwala dostrzec wyjątkowość oraz złożoność człowieka, który doświadcza siebie poprzez swoją cielesność i psychikę, wrażliwość moralną i duchową, więzi z Bogiem, z samym sobą, a także z innymi osobami. Antropologia biblijna ukazuje także ludzką słabość, zdolność do złego oraz potrzebę czujności, pracy nad sobą i współpracy z łaską. Dzięki takiemu naświetleniu tajemnicy człowieka stwarza ona szansę na pełne ujęcie i zrozumienie człowieka, który potrzebuje wychowania i łaski, aby stawać się „obrazem i podobieństwem Boga na ziemi”"13 - tak Bojanowski określił najwyższy cel wychowania. Ze względu na wielkie znaczenie wczesnego rozwoju oraz wychowania dziecka konsekwentnie zmierzał do stworzenia integralnej koncepcji pedagogicznej ujmując szeroki kontekst życia człowieka w wymiarze indywidualnym i społecznym, doczesnym i nadprzyrodzonym.

Realistyczne ujęcie człowieka, jakie proponuje myśl klasyczna, znalazło wyraz w myśli pedagogicznej Bojanowskiego za sprawą Jana Koźmiana (1814-1877), który krytycznie odnosząc się do modnego wówczas idealizmu niemieckiego ${ }^{14}$, ukierunkowywał jego poszukiwania i refleksję na szeroko rozumianą filozofię klasyczną, zarówno starożytną, jak i scholastyczną, o czym świadczą dokumenty źródłowe. Nie oznaczało to jednak bezkrytycznego powielania metody uprawiania filozofii w wiekach średnich. Koźmian pisze, że „dziś minęły czasy dysput po szkołach, dziś

\footnotetext{
${ }^{11}$ Zob. AGSD, B-k-1, k.7-8; B-h-1, k.11-42; k. 68v-10o; B-h-3, k.54v-73.

${ }^{12}$ Por. Tomasz Stępień, Wprowadzenie do antropologï filozoficznej św. Tomasza z Akwinu (Warszawa: Warszawskie Towarzystwo Teologiczne 2013), 63.

${ }^{13}$ AGSD, B-h-1, k. 18v.

${ }^{14}$ Por. Jan Koźmian, Pisma (Poznań: Drukiem i nakładem Jarosława Leitgebra 1881), 10.
} 
więcej niż kiedy trzeba nauki żywej; otóż wierzymy gorąco i będziemy się starali wykazywać, że tą nauką żywą jest tylko katolicyzm"15. Także współpraca ze zmartwychwstańcami - ks. Hieronimem Kajsiewiczem (1812-1873) i ks. Piotrem Semenenką (1814-1886) ukierunkowała jego myśl teologiczno-filozoficzną na płaszczyznę realizmu filozoficznego ${ }^{16}$. Szczególnie za pośrednictwem Semenenki miał możliwość zapoznania się z filozofią tomizmu tradycyjnego i neoscholastyką.

Bojanowski, budując koncepcję wychowania, odwołał się do Biblii, dorobku ludzkiej myśli w dziedzinie filozofii, literatury, historii oraz współczesnej myśli i praktyki pedagogicznej. W swej refleksji nad wychowaniem w jego szczegółach wychodził od poznania i jasnego sformułowania założeń. Dokonywał tego zawsze w odniesieniu do natury, religii i historii. Tworzył w ten sposób pełny kontekst życia, rozwoju i edukacji osoby opisany w wymiarze uniwersalnym, odnosząc się do religii i filozofii oraz w specyficznym - do historii i narodowości.

W kontekście silnych tendencji oświeceniowych, a także pozytywistycznych, zmierzających do eliminowania wiary i religii oraz wpływu Kościoła na życie i wychowanie człowieka jasna deklaracja religijno-filozoficzna stawała się koniecznością. Koźmian wspierał Bojanowskiego w tej jednoznaczności i rozeznawaniu między realizmem a idealizmem. W „Przeglądzie Poznańskim” z 1845 roku pisał: „Pożądana wielce jest szczerość w zwyczajnych na świecie stosunkach, daleko pożądańsza we wszelkich robotach publicznych. Kto pisze, a szczególniej, kto zamierza sobie przez pismo czasowe działać na umysły, powinien wyraźnie powiedzieć czego chce i cały kierunek dążeń swoich wytknąć. [...] Prawdą bezwzględną jest dla nas objawienie chrześcijańskie, powagą Kościoła katolickiego zatwierdzone, jednym słowem jesteśmy katolikami. To oświadczenie wystarczy przynajmniej do czasu, żeby pokazać jak pojmujemy Boga, stworzenie i stosunek Boga do stworzenia, co myślimy o duszy nieśmiertelnej. Ale każda prawda bezwzględna, a tym bardziej prawda objawiona, musi się pomimo niezmienności swojej treści wewnętrznej, wyrażać w czasie, na zewnątrz, odpowiednimi stanowisku ciągle żyjącej myśli ludzkiej układami (systematami). Tłomaczymy się jaśniej. Dla filozofii dzisiejszej zwłaszcza niemieckiej, wszelkie objawienie jest prawdziwe, ale względnie, docześnie; właściwie każda religia, każdy układ filozoficzny jest objawieniem; nam, powtarzamy, objawienie chrześcijańskie dopiero jest prawdą bezwzględną i ta prawda w niewzruszonych dogmatach pod strażą Kościoła spoczywa. Wiara przyjmuje objawienie, a przyjmuje je w całości, ale jest ono zarazem koniecznym przedmiotem badań rozumu (wyraz rozum bierzemy w najobszerniejszem znaczeniu). Kto wierzy, ma obowiązek nad treścią wiary swojej łamać władze duszy nieśmiertelnej”"17.

Dalej kontynuuje: „Oczywistą jest rzeczą, że dla tej filozofii, którą wszelkim prawem nazwać można katolicką, stanowisko prawdy do rozumu jest zupełnie przedsobne (objectivum), co postaramy się objaśnić i udowodnić w następstwie. Atoli

\footnotetext{
${ }^{15}$ Tamże, 4 .

${ }^{16}$ Por. Maria Opiela, „Zespolenie idei narodowej, odrodzenia religijnego z pracą społeczną dla rozwoju rodzimej koncepcji wczesnej edukacji”. Polska Myśl Pedagogiczna 1 (2015): 153-154.

${ }^{17}$ Koźmian, Pisma, 4.
} 
z prostego już postawienia kwestyi wypływa, że filozofia dzisiejsza zacząwszy od Descarta właśnie przeciwny obrała kierunek, to jest, że wedle niej prawda względem rozumu ma stanowisko wsobne (subjectivum): ztąd jednostronność, ztąd niepłodność układów nowszych. Stanowisko to odwrotne tak się upowszechniło w ostatnich czasach, że nawet filozofowie katoliccy prace swoje na podstawie wsobności pobudowali i namnożyło się, szczególniej wobecnej chwili, w łonie samejże katolickiej nauki, układów opartych na owej jednostronnej zasadzie"18. Ta wykładnia przyjętych założeń wskazuje na realizm filozoficznego poznania, wyjaśniającego rzeczywistość człowieka w sposób całościowy i realistyczny, a jednocześnie uwzględniający wewnętrzne i zewnętrzne uwarunkowania jego rozwoju.

W tak bardzo istotnych kwestiach sprawa wychowania, które Bojanowski uważał za drogę pełnego rozwoju człowieka oraz odrodzenia moralnego i religijnego narodu oraz ludzkości, wymagała doprecyzowania podstaw teoretycznej refleksji, a także organizowania go w praktyce. Pójście drogą tradycji kościelnej i praktyka wychowawcza gwarantowały trwanie przy realistycznej wizji złożonej rzeczywistości człowieka oraz jego działania w świecie. O tym, jak ważne było dla niego wsparcie Koźmiana w tym względzie, świadczy ich korespondencja. W 1855 roku Bojanowski napisał: „List Pański wielce ożywił we mnie nadzieję przyprowadzenia do skutku Bractwa Ochronkowego, które lubo miałem zawsze na celu przy urządzaniu ochronek, nie śmiałem przecież dotąd przystąpić bliżej ku temu, nie znajdując nikogo, coby skutecznym poparciem moich usiłowań, obiecywał mi pomyślne osiągnięcie celu. Teraz dopiero w radzie i pomocy Pańskiej zupełną pokładam ufność zorganizowania nareszcie tej instytucji i mam w Bogu nadzieję, że przy takowym namaszczeniu religijnym, zaczęlaby dopiero prawdziwie błogie wydawać owoce. Wszystko, co mi Kochany Pan piszesz w tym względzie, trafia mi niezmiernie do serca i za niezbędne poczytuję warunki ku należytemu rozwinięciu Ochronek. Chciej Pan tylko nadal nie odmawiać mi Swej najłaskawszej pomocy, a przede wszystkim wskazać istniejące już reguły, które by za wzór wziąć wypadało. Powzięte z dotychczasowych Ochronek doświadczenie posłuży dostatecznie do uzupełnienia reszty. Nie mam tu nikogo, coby mnie oświecił w tym względzie, dlatego ośmielam się Kochanego Pana tym trudzić. Wszelkich potrzebnych wskazówek z największym upragnieniem wyglądać będę i całej usilności dołożę, aby jak najprędzej z nich korzystać" 19 .

Bojanowski z wykształcenia nie był filozofem ani teologiem, a czerpał wiedzę z nauczania i tradycji kościelnej, w czym ideowo oraz naukowo wwymiarze teologiczno-filozoficznym wspierał go Koźmian oraz Semenenko. Wykorzystując swą bogatą wiedzę z dziedziny literatury, historii, kultury, filozofii, którą zdobył w czasie studiów we Wrocławiu oraz Berlinie, gdzie zetknął się zidealizmem i jego zastosowaniem także wliteraturze oraz rozwijających się koncepcjach

\footnotetext{
${ }^{18}$ Tamże, 5 .

19 „Edmund Bojanowski do Jana Koźmiana w Kopaszewie, 25.01.1855 r”, w: Korespondencja Edmunda Bojanowskiego z lat 1836-1871, t. I, red. Leonard Smołka (Wrocław: Zgromadzenie Sióstr Służebniczek Najświętszej Maryi Panny 2001), 145.
} 
pedagogicznych, Bojanowski potrzebował takich wskazówek służących rozeznaniu istoty fundamentu. Stąd biblijna koncepcja człowieka i chrześcijańska filozofia leżą u podstaw, wyznaczając kierunek oraz charakter formułowanych przez niego celów, zasad wychowania oraz praktycznej ich realizacji. W tym kontekście odpowiedzi na pytanie: „kim jest człowiek?” określają i wyjaśniają konieczność, granice oraz możliwości wychowania człowieka, podejmują kwestię podmiotowości, wolności, a także odpowiedzialności człowieka w wychowaniu. Przyjęta adekwatna antropologia stanowiła punkt wyjścia dla określania podstaw teorii wychowania i odpowiadania na pytania o wychowanie, jego istotę, cele i zasady wspierania integralnego rozwoju osoby. Bojanowski dociekliwie szukał tego, co wspólne wszystkim ludziom - istoty człowieczeństwa, by wtym kontekście rozpoznawać oraz formułować zasady i szczegóły integralnego wychowania ${ }^{20}$.

Korzystał z dorobku myśli pedagogicznej, analizując dzieje ludzkości, rozpoznając skrajności pojawiające się $\mathrm{w}$ różnych epokach i konsekwentnie zmierzał do stworzenia własnej koncepcji wychowawczej. Umiejętnie czerpał $\mathrm{z}$ różnych doświadczeń, rozwiązań praktycznych, dokonując syntezy oraz wyboru tego, co było godne uznania. Zwracanie uwagi na wartość natury, wychowywanie dziecka zgodnie z nią nie oznaczały dla Bojanowskiego bezkrytycznego przyjęcia naturalizmu Rousseau, lecz były wyrazem reakcji na rozpowszechniającą się w tym okresie negację prawa naturalnego oraz jego roli w dziedzinie moralnej i socjalnej. Takie negatywne nastawienie prezentował historyzm i pozytywizm w XIX wieku ${ }^{21}$. Przyjęta przez niego filozoficzna koncepcja człowieka oraz odniesienie do wartości chrześcijańskich pozwoliło właściwie poznawać, a także rozumieć wartość świata natury, którego człowiek jest cząstką, jego cielesności oraz odwiecznego prawa naturalnego wpisanego w naturę człowieka. Znał i doceniał wkład Rousseau w tej dziedzinie, ale miał krytyczny stosunek do zastosowania idei naturalizmu: „Atoli nowy ten kierunek jakkolwiek nie przeminął bez korzystnego na ludzkość wpływu [...] wywołał w oświeceńszych stanach niemniej szkodliwe znowu rozwolnienie i ślepą pobłażliwość we wychowaniu dziecięcym. Skąd dzika swawola, przesyt zbytków, zmiękczenie ciała, a przedwczesne wysilanie umysłu i zgubna częstokroć wiadomość stosunków życia dojrzalszego, wkradły się pod imieniem naturalnej wolności”22. To wyraźny przykład jego pełnej realizmu postawy wobec istotnych kwestii odnoszących się do świadomego kształtowania podstaw swej koncepcji. Za realizmem przemawia ujęcie wolności jako trwania przy dobru i prawdzie; godnośc, aretologia. Są one bliskie Bojanowskiemu, obecne w jego pedagogice.

\footnotetext{
${ }^{20}$ Por. Opiela, Integralna, 221-224.

${ }^{21}$ Zob. Mieczysław A. Krąpiec, Człowiek i prawo naturalne (Lublin: Polskie Towarzystwo Tomasza z Akwinu 2009), 11-13.

${ }^{22}$ AGSD, B-h-1, k. 11v.
} 


\section{Istotne elementy koncepcji integralnego wychowania Edmunda Bojanowskiego i systemu wczesnej edukacji}

W opracowanym przez Bojanowskiego zarysie sytemu wychowania ${ }^{23}$ wyraźnie w centrum wskazanych tam elementów znajduje się osoba dziecka i wychowawczyni. Wszystkie inne wskazują na uwarunkowania kontekstu oraz organizacji ochrony osoby przez wychowanie.

U podstaw rozumienia procesu wychowania, który Bojanowski określił mianem „nauka”, leży takie samo założenie, z jakiego wychodzą współcześni przedstawiciele filozofii wychowania przedstawiający propozycję pedagogiki, która opiera się na realizmie epistemologicznym i bytowym. Jest nim przekonanie, że wychowuje się i kształci całego człowieka zgodnie z jego strukturą bytową, zatem nie można pedagogiki redukować do któregoś z jej elementów albo do jakiegoś aspektu egzystencji lub działania. Człowiek jako osoba, będąc jednością duszy oraz ciała, powinien być wychowany i kształcony integralnie. Wychowanie integralne obejmuje intelekt, wolę oraz uczucia, a także władze zmysłowe, prowadząc do harmonii władz, sprawności i czynów człowieka. „Umożliwia to wykształcenie intelektu, który «po królewsku» dogląda funkcjonowania woli człowieka. Sprawności podążają za człowiekiem w jego życiu osobistym i społecznym, chroniąc go przed fałszem i złem obecnym w kulturze, ucząc wierności temu, co dobre i prawdziwe, integrując jego działania”24.

W zapisach dotyczących swej koncepcji wyróżniał na przykład: „A. Kształcenie fizyczne. (Gimnastyka) [...]; B. Kształcenie moralne. (Muzyka) [...]; C. Kształcenie obyczajowe. (Etyka)"25. Tu znajdujemy grecki kanon wychowania - kalokagathia ${ }^{26}$. Kierując się wskazaną wyżej zasadą analizy rzeczywistości człowieka i świata oraz pełnego ich ujęcia, dokonał analizy przeszłości wodniesieniu do zjawiska wychowania, społeczno-kulturowych uwarunkowań czasu i środowiska, co pozwoliło stworzyć system odpowiadający na ówczesne potrzeby. Integralność temu złożonemu procesowi poznania i rozumienia rzeczywistości człowieka zapewniało konsekwentne odniesienie do chrześcijaństwa. Zmierzając do poznania istoty danego zjawiska, za niezbędne uznawał zdobycie jak najszerszej perspektywy jego oglądu. Tę perspektywę wyznaczał wymiar natury (fizyczny), religii (duchowy) i historii (czasowoprzestrzenny, kulturowy).

Takie ujęcie rzeczywistości stanowiło podstawę organizacji rozwiązań systemowych, zapewniając warunki integralnego rozwoju i wychowania dzieci. Jego celem było kształtowanie szlachetnych, mocnych charakterów dobrych chrześcijan

\footnotetext{
${ }^{23}$ AGSD, B-h-2, k. 1-2r.

${ }^{24}$ Mikołaj Krasnodębski, Integralna antropologia wychowania. Filozofia wychowująca tomizmu konsekwentnego (Białystok: Niepaństwowa Wyższa Szkoła Pedagogiczna 2013), 70-71.

${ }^{25}$ AGSD, B-h-2, k. 10vi i11r.

26 Zob. Mikołaj Krasnodębski, Człowiek ipaideia. Realistyczne podstawy filozofii wychowania (Warszawa: Szkoła Wyższa Przymierza Rodzin 2009), 114.
} 
i uczciwych obywateli, by w konsekwencji sami doszli do osiągnięcia najwyższego celu wychowania - aby każdy stał się obrazem i podobieństwem Boga na ziemi. Określone przez Bojanowskiego ujęcie procesu wychowania umiejscawia je w koncepcji klasycznej pedagogiki. Miał on na myśli wychowanie obiektywne, zbudowane na realistycznej wizji człowieka (konkretnie - katolickiej), powstałej w obrębie cywilizacji łacińskiej, która zasymilowała dorobek greckiej paidei²7. Dokonał analizy dziejów, by stworzyć syntezę założeń i wskazań dla harmonijnego rozwoju ciała oraz duszy dziecka od najmłodszych lat. Przyjął metodę sokratyczną w swych analizach i polecił stosować ją w praktyce edukacyjnej28. Odwoływał się między innymi do Platona, który „pierwotne wychowanie dzieci do najważniejszych spraw narodowych licząc, rozwinął w nim głębokie nad podziw zasady i do publicznej instytucji onegoż zostawił pierwszy pomysł, który dopiero za najnowszych czasów zaczął się urzeczywistniać [...] starożytność, będąc młodocianą epoką całej ludzkości, jak z jednej strony swym wszechstronnie uzmysłowionym i prostym wedle natury życiem, dawała dziecięcemu kształceniu korzystny i przystępny z siebie wzór do naśladowania; tak nie mniej i dla wszystkich następnych czasów została w tym względzie najlepszą mistrzynią"29.

Bojanowski, doceniając starożytność, zgodnie z dialektyką heglowską dążył do jej „wpisania” w to wszystko, co oferowała mu ówczesna humanistyka i pedagogikaº. Poznania i rozumienia dorobku myśli poszczególnych epok dokonywał konsekwentnie w kontekście swej wizji rzeczywistości, podstawą której jest chrześcijańska antropologia oraz etyka. Tak uniknął bezkrytycznego korzystania z błędnych koncepcji filozoficznych, a sytuacje, działania, metody i środki wychowawcze dobierał zgodnie z założeniami antropologicznymi.

Oparte na realizmie podejście Bojanowskiego do życia, świata i działania charakteryzowała postawa zmierzająca do budowania harmonii we wszystkich wymiarach egzystencji człowieka, a także rzeczywistości, w której on żyje. Opierając się na wierze, uwzględniał odrębność prawa naturalnego, w którym wszystkie wymiary rozwoju osoby zyskują właściwe znaczenie jako dzieła Bożego, w stosunku do prawa stanowionego przez człowieka i wpisanego w historię ludzkiego działania. Z prawa naturalnego wynika, iż istota ludzka jest zdolna do rozumienia oraz czynienia dobra i zła w stosunku do innych. Poznając złożoność zjawisk w wymiarze dziejów ludzkości, świata natury oraz kultury, miał świadomość wielości, różnic, sprzeczności. Natomiast poznawanie stałości praw, a także bogactwa rzeczywistości religijnej prowadziło go do porządkowania według nich rzeczywistości doczesnej ${ }^{31}$.

Innym wyrazem realizmu koncepcji Bojanowskiego jest poznawanie oraz całościowe ujmowanie warunków życia, rozwoju idziałania zgodnych z naturą

\footnotetext{
${ }^{27}$ Por. tamże, 21.

${ }^{28}$ Por. AGSD, B-h-2, k. 1r, 2r.

${ }^{29}$ AGSD, B-h-1, k. 11r.

${ }^{30}$ E. Bojanowski werbalnie był pod urokiem Hegla, filozofię którego poznał studiując w Berlinie.

${ }^{31}$ Por. Opiela, Integralna, 42.
} 
człowieka. Wynikało to także z przyjętej antropologii, zgodnej z rzeczywistością, $\mathrm{z}$ bytową zawartością człowieka, z tym, kim on jest na każdym etapie swego życia i rozwoju. „Zgodne z prawdą rozeznanie, kim jest człowiek, ma doniosłe znaczenie pedagogiczne. Pozwala ono nawiązać relację wychowawczą, która będzie opierała się na realnym, a nie wyimaginowanym dobru człowieka, zgodnym z prawdą o nim" 32 . Tak postrzegał dziecko i dzieciństwo we wczesnym wychowaniu, obejmującym okres od urodzenia do rozpoczęcia nauki w szkole. Liczenie się z prawami rozwoju oraz indywidualnymi możliwościami dziecka, zachowanie odpowiednich proporcji we wszystkich obszarach jego osobowości zapewniało optymalne warunki wspierania pełnego rozwoju dziecka i ksztaltowania fundamentu jego życia. Świadomość wielkiego znaczenia wczesnego rozwoju oraz wychowania prowadziła go do stworzenia koncepcji pedagogicznej ujmującej szeroki kontekst życia człowieka w perspektywie natury, religii, historii. Wszystkie elementy tego procesu dogłębnie przeanalizował oraz określił, uwzględniając wymiar indywidualny i społeczny, doczesny i nadprzyrodzony.

Prowadzone przez Bojanowskiego analizy myśli ludzkiej oraz cywilizacji wskazują, że jeżeli rzetelnie poznajemy dzieje ludzkości, musimy uczciwie przyznać, iż zawsze obok niejednokrotnie dominujących skrajnych wizji istoty ludzkiej obecna jest biblijna koncepcja człowieka afirmująca go jako osobę kochaną nieskończenie przez Boga. Wraz z rozwojem nauk filozoficznych i empirycznych koncepcja ta zyskuje nowe, pogłębione rozumienie zarówno istoty rozwoju osoby, jak i zjawiska jego edukacji na poszczególnych etapach. Jest ona gwarantem kierowania się w procesie kształcenia dziecka jego najwyższym dobrem, z poszanowaniem godności ludzkiej natury, prawa do integralnego rozwoju i wychowania opartego na miłości oraz odpowiedzialności. Wszystko zatem, do czego ludzkość dochodzi na drodze rozwoju nauki, kultury, techniki, gospodarki powinno służyć każdej osobie do osiągania pełni rozwoju w wymiarze doczesnym i nadprzyrodzonym. Jednocześnie poprzez edukację, której osoba jest czynnym uczestnikiem, ma zmierzać do poznania prawdy i wyboru dobra, by w wolności podejmować odpowiedzialność za siebie oraz innych.

Rozumienie rzeczywistości świata i człowieka zanurzonego w świecie, współżyjącego z innymi osobami prowadzi do odkrywania wewnętrznego imperatywu do życia oraz działania zgodnie z tym prawem, a także wynikających stąd powinności. Przyjmując analogiczną strukturę rzeczywistości oraz właściwy jej sposób poznawania, rozumienia Bojanowski sytuuje się ze swą koncepcją w realistycznej filozofii tomistycznej. Dlatego rekonstrukcja jego integralnej pedagogiki znalazła tutaj swoje podstawy33.

\footnotetext{
${ }^{32}$ Mikołaj Krasnodębski, „Antropologiczne podstawy pedagogiki integralnej”, w: Wychowanie integralne w edukacji katolickiej. Idee - twórcy - instytucje, red. Maria L. Opiela, Ewelina Świdrak, Małgorzata Łobacz (Lublin: Wydawnictwo KUL 2014), 23-24.

${ }^{33}$ Por. Opiela, Integralna, 322.
} 


\section{Realizm w podstawach procesu zmian adaptacyjnych i zachowania tożsamości koncepcji w pedagogice integralnej}

Służebniczkom w poszukiwaniach odpowiedzi na pytanie, czy i w jaki sposób można dzisiaj korzystać z pedagogicznych wskazań Bojanowskiego, realizując jego koncepcję wychowania, zawsze towarzyszyła troska o wierną kontynuację jego myśli i dzieła. Wynika to zobowiązku wierności charyzmatowi oraz pierwotnej inspiracji Założyciela, a najpewniejszą drogę rozeznania znajduje w realizmie, czyli liczeniu się z rzeczywistością w porządku poznania, działania, wytwarzania34. W pełnym kontekście prawdy o człowieku oraz uwarunkowań jego życia i rozwoju ważne jest odniesienie do integralnej antropologii, która z uwagi na swój realizm budowana jest na rzetelnym poznaniu istniejącego świata oraz na takich założeniach, które dzięki religii i filozofii ujmują wymiar doczesny i nadprzyrodzony rzeczywistości, umożliwiając właściwą adaptację oraz zachowanie tożsamości koncepcji integralnego wychowania. One bowiem stanowią także argument dla realizowanego wychowania katolickiego, określenia jego teoretycznych podstaw (integralna pedagogika przedszkolna) i praktycznej ich realizacji (program wychowania, metodyka).

Prowadzona przez ponad 160 lat działalność pedagogiczna Stużebniczek pokazuje, że wielokrotnie w sytuacji kwestionowania jej charakteru konieczne było odwołanie do tego argumentu. Sięganie do systemu Bojanowskiego wymaga całościowego jego widzenia i traktowania, bo tylko wówczas jest zgodne z modelem wychowania i opieki, który znalazł się u podstaw działalności opiekuńczo-wychowawczej Sióstr Służebniczek BDNP i który nadal gwarantuje pozytywne efekty przy zachowaniu jej tożsamości. Chociaż z biegiem czasu działalność wochronkach ulegała przeobrażeniom, tak pod wpływem presji wymagań zewnętrznych, jak i celowych zabiegów adaptacyjnych, to jednak pozostała wierna swej istocie35.

Od początku dostrzega się w Zgromadzeniu potrzebę kontynuacji przyjętego przez Bojanowskiego stylu poznawania oraz rozumienia sensu ludzkiego życia i działania, aktualnych problemów, potrzeb człowieka, a także świata, na które siostry mają odpowiadać w swej praktyce pedagogicznej. Bez właściwego rozpoznania obszaru zmienności, a równolegle - ciągłości tej działalności wobec aktualnych potrzeb i problemów społecznych może ona utracić swą specyfikę, nie stanowiąc kontynuacji pierwotnych założeń. Natura człowieka nie zmieniła się, zatem nie zdezaktualizowały się ideały i cele wychowania, ale stało się tak dlatego, że sięgały one dalej niż wartości tylko czysto naturalne czy społeczne. Podstawą trwałości i ciągłości jest oparta na mocnych podstawach religijno-filozoficznych uniwersalna, chrześcijańska koncepcja człowieka. Te elementy stanowią stałe odniesienie w systematycznej refleksji (podejmowanej przez kapituły przynajmniej co 6 lat) nad aktualnością i wiernością myśli Założyciela ${ }^{36}$.

\footnotetext{
${ }^{34}$ Zob. Mieczysław A. Krąpiec, „Filozoficzny realizm”, w: Powszechna Encyklopedia Filozofii, t. III (Lublin: Polskie Towarzystwo Tomasza z Akwinu 2002), 541.

${ }^{35}$ Zob. Opiela, Dynamika, 23-24.

${ }^{36}$ Por. Opiela, Integralna, 282-283.
} 
Obszarem zmiany, dzięki któremu działalność ochronkowa może, a nawet powinna być adaptowana do aktualnej sytuacji, są konkretne formy, metody oraz środki pedagogicznego działania. W ich doborze nie należy kierować się modą czy też bezkrytycznym korzystaniem z nowości, ale możliwościami oraz potrzebami rozwojowymi osoby dziecka jako podmiotu tej działalności, bez zagrożenia kontynuacji; tu wskazane jest ich doskonalenie z wykorzystaniem dorobku ludzkiej myśli i technologii. Zmieniające się warunki kształtowały także w przeszłości sposoby zachowania oraz relacji ochroniarek ze środowiskiem, ich dobór i przygotowanie, określały także zakres działań. Natomiast motywacja ich podjęcia oraz realizacji zawsze wynikała z odpowiedzialności za wierną realizację charyzmatu Założyciela, który odnosi się do wartości wyższych, absolutnych ${ }^{37}$.

Bojanowski zbudował koncepcję trwałą, a równocześnie elastyczną. Dostrzegał wzajemne zależności między tym, co niezmienne (dlatego też stanowi stały punkt odniesienia, źródło celów i zasad, zapewniając ciągłość działaniom) oraz tym, co zmienne (a co gwarantuje rozwój, postęp, adaptację oraz realizację celów w zmieniających się warunkach). Dając takie podstawy swemu dziełu, zapewnił mu właściwą dynamikę regulowaną przez założone od początku procesy ciągłości i zmiany. Na tej podstawie rekonstrukcja systemu pedagogiki Bojanowskiego jest z jednej strony kontynuacją jego myśli pedagogicznej, a z drugiej - wynika z jego rozumienia przez Służebniczki.

Odkrywanie w przeszłości tego, co istotne w wychowaniu, służy podjęciu swego rodzaju dialogu z budowanymi i realizowanymi na przestrzeni dziejów ludzkości teoriami oraz koncepcjami wychowania. Bojanowski wychodził z założenia, że współczesność potrzebuje swoistej syntezy dotychczasowych doświadczeń, które znajdowały wyraz w życiu i kulturze społeczeństwa, z jednej strony po to, aby zachować oraz dobrze wykorzystać wszystko, co dobre w budowaniu spójnego spojrzenia na wychowanie, z drugiej zaś, kierując się świadomością biegu procesu zmian cywilizacyjnych, kontynuować pierwotny zamiar, nadając mu sens, a także interpretować zjawiska w kontekście horyzontów poznawczych współczesnych dyskursów o edukacji przy zachowaniu swej tożsamości38.

Wraz z rozwojem nauk pedagogicznych, filozofii, psychologii oraz katolickiej nauki społecznej rozwijały się teoretyczne podstawy tej działalności stanowiące interpretację pierwotnych założeń. Już wXIX wieku pedagogia Bojanowskiego przyczyniła się do podania pedagogicznej odpowiedzi na problemy życia społecznego, sprawdziła się w tej roli wzmieniających się warunkach społeczno-kulturowych i politycznych, zachowując swą tożsamość. Analiza fenomenologiczno-hermeneutyczna pozwoliła przejść od pedagogii Bojanowskiego do jego pedagogiki, czego podstawę stanowią pisma zawierające takie same teoretyczne założenia, do jakich nawiązuje współczesna wiedza pedagogiczna. Żywe związki z postępami tej wiedzy zachowały się do dzisiaj, a szczególnie ważny dla kontynuacji pierwotnych założeń był czas do połowy

\footnotetext{
${ }^{37}$ Por. Opiela, Dynamika, 126-127.

${ }^{38}$ Opiela, Integralna, 58.
} 
ubiegłego wieku, kiedy prężnie rozwijały się podstawy pedagogiki katolickiej. Natomiast w okresie transformacji kontynuacja założeń pedagogii domagała się określenia podstaw teoretycznych, jednak nie poprzez tworzenie, lecz odkrycie ich na nowo. To dokonuje się od wielu lat poprzez analizy pism Bojanowskiego oraz działalności wychowawczej Zgromadzenia (z uwzględnieniem pełnego ich kontekstu wynikającego z miejsca i czasu). Jest to dynamiczny proces, w którym, opierając się na dorobku ogólnej pedagogiki o inspiracji chrześcijańskiej, zostały opracowane podstawy tej subdyscypliny pedagogiki, jaką jest integralna pedagogika przedszkolna w stanie tworzenia ${ }^{39}$.

Rekonstrukcja integralnej pedagogiki przedszkolnej Bojanowskiego oraz prezentacja jej istotnych elementów oraz uwarunkowań, zarówno od strony merytorycznej, jak i historycznej, jest kontynuacją jego refleksji teoretycznej oraz systemu realizowanego i doskonalonego przez Służebniczki. Stanowi kontynuację zamiaru Założyciela: utrzymanie dynamiki rozwoju uwzględniające zmianę pozwalającą na równoczesne zachowanie tożsamości. Wychodzimy z założenia, które przyjął Bojanowski, iż religia katolicka (teologia katolicka) i filozofia realistyczna określają ogólne podstawy myśli pedagogicznej, rozwijającej się wraz z nimi.

Wpisany w koncepcję wychowania aspekt ochrony dzieci zyskuje współcześnie odzwierciedlenie i głębsze zrozumienie w,etyce chronienia osób” Mieczysława Gogacza ${ }^{40}$. „Punktem wyjścia i celem tej etyki nie jest ani interpretacja doświadczenia moralnego, ani antropologia filozoficzna. Jej punktem wyjścia są relacje, które nawiązują realnie istniejące osoby. Celem - zbudowanie reguł sprzyjających moralnemu rozwojowi człowieka, jego metanoi tak, by człowiek służył człowiekowi prawdą i dobrem, by przez rozumne decyzje podtrzymywał osobowe relacje. [...] Na realności, prawdzie i dobru nawiązują się osobowe relacje. Dzięki realności osoby powstaje osobowa relacja życzliwości (miłości), na prawdzie - relacja otwartości (wiary), zaś na dobru - relacja zaufania (nadziei), czyli trwania przy osobie jako przy dobru"41. Poruszając się zatem whoryzontach analizy określonych przez Bojanowskiego oraz wynikających z nich odniesień do inspiracji filozoficzno-religijnych, pedagogicznych i Tradycji, opisano na nowo proces wczesnej edukacji, relacje osobowe pomiędzy uczestnikami sytuacji wychowawczej: dorosłym i dzieckiem, a także kształcenie i formację wychowawczyń oraz instytucję ochronki we współczesnym kontekście filozoficznym i społeczno-kulturowym.

Takie podejście zawsze służyło pogłębionej refleksji nad praktycznym i teoretycznym wymiarem wychowania przedszkolnego realizowanego w instytucji ochronki - przedszkola. Potrzeba kontynuacji zabezpieczała przed pochopnym porzucaniem właściwego sobie stylu wychowania w imię nowinek bądź z powodu obaw przed byciem nienowoczesnym. Szerzące się idee Nowego Wychowania i związane z tym ruchem teorie były Służebniczkom znane, a słuszne idee - brane pod uwagę. Teoretyczne oraz praktyczne wskazania Bojanowskiego pozostawały wciąż

\footnotetext{
${ }^{39}$ Por. Stanisław Palka, Pedagogika w stanie tworzenia (Kraków: Wydawnictwo UJ 1999).

${ }^{40}$ Zob. Mieczysław Gogacz, Wprowadzenie do etyki chronienia osób (Warszawa: Wydawnictwo Navo 1993); tegoż, Ku etyce chronienia osób (Warszawa: Wydawnictwo Pallotinum 1991).

${ }^{41}$ Krasnodębski, Integralna, 6o-61.
} 
aktualne, zatem sprawdzały się w różnych sytuacjach społeczno-kulturowych na przestrzeni ostatniego wieku. Podkreśla się zresztą fakt, że „teoria i praktyka wychowawcza Bojanowskiego wyprzedzały znacznie osiągnięcia wielu jego następców czy też pedagogów tworzących zręby tej dyscypliny naukowej"42.

Posługując się hermeneutyką odnowy w ciągłości należy się odnieść do założenia, które przyjął już Bojanowski, że praktyka wychowania stanowi źródło teorii, a teoria pomaga doskonalić praktykę. Ta wzajemna zależność, historyczność oraz realistyczna koncepcja człowieka stanowią ważne wymiary podejścia zmierzającego do kontynuacji tradycji myśli, a także praktyki wychowania. Chodzi także o jej rozwijanie i udoskonalanie ze względu na potrzeby oraz wyzwania, przed którymi staje człowiek żyjący w zmieniającej się rzeczywistości współczesnego świata. Poznanie i rozumienie tego, co wymaga kontynuacji, dokonuje się w horyzoncie niezmiennych wartości najwyższych, natury ludzkiej, a także historii. Odnowy wymagają formy, środki jako zdobycze cywilizacji i wytwory ludzkiej myśli i działalności ${ }^{43}$, której zmienność nie zawsze prowadzi do rozwoju, lecz niejednokrotnie staje się regresem. Dlatego odnosimy się do religii katolickiej i filozofii realistycznej, by odkrywać, a następnie coraz głębiej rozumieć to, co niezmienne w swej istocie, uniwersalne, aby w tym świetle interpretować swoiste, cząstkowe, indywidualne, będące urzeczywistnieniem tego, co powszechne, w życiu osoby i jej drogi rozwoju do pełni człowieczeństwa.

Refleksja służąca kontynuacji myśli Bojanowskiego przez Służebniczki znajdowała swe odniesienia w rozwijającej się pedagogice katolickiej. Wyraźnie widać to w zachowanych podręcznikach i literaturze gromadzonej przez siostry dla celów formacyjnych. W przygotowaniu sióstr do pracy wychowawczej zawsze bardzo ważne są dwie współwystępujące drogi. Jedna to formacja do apostolatu, w której istotne jest nabywanie oraz doskonalenie postaw zgodnych z wiarą katolicką, odniesienie do Kościoła jako instytucji wychowawczej i jego nauki społecznej, poznanie zasad wychowania oraz podstaw teoretycznych określonych w pedagogice jako nauce, a sprawdzonych w pedagogii katolickiej. Drugą jest kształcenie pedagogiczne zmierzające do studiowania pedagogiki jako nauki zawierającej wszystkie odmiany współczesnego dyskursu, prowadzenie badań pedagogicznych, a także nabywanie kompetencji zawodowych odpowiadających wymogom prawa oświatowego. Stałość i kontynuacja pierwszej drogi pozwala umiejętnie korzystać zcałego dorobku ludzkości w dziedzinie pedagogiki poprzez stosowanie wszystkiego, co pozytywne, trwałe w wynikach jej badań, a co służy osiąganiu celów integralnego rozwoju i wychowania osoby bez utraty chrześcijańskiej tożsamości. J. Woroniecki, kreśląc program integralnej pedagogiki katolickiej, podał konkretne warunki, jakie powinna spełniać pedagogika, aby miała prawo zwać się katolicką44.

42 Irena Adamek, Przygotowanie dzieci do szkohy w warunkach rozwijającego się wychowania przedszkolnego na ziemiach polskich (druga połowa XIX wieku - 1918 rok) (Kraków: Wydawnictwo Naukowe WSP 1999), 38.

${ }^{43}$ Zob. Opiela, Dynamika, 170-184.

${ }^{44}$ Jacek Woroniecki, „Program integralnej pedagogiki katolickiej”. Ateneum Kaptańskie 39 z. 1 (1947): 2836, z. 2: 165-174, z. 3: 272-281. 


\section{Zakończenie}

Oderwanie od filozoficzno-religijnych, chrześcijańskich korzeni i motywacji w dziedzinie wychowania, od formułowanej w tym kontekście koncepcji człowieka jako osoby, prowadzi do zagubienia w myśli teoretycznej, a jeszcze bardziej dramatycznego - zagubienia człowieka w świecie. W takiej sytuacji pojawia się potrzeba budowania pogłębionego spojrzenia teologiczno-filozoficznego jako źródła inspiracji dla refleksji pedagogicznej, którego potrzebuje dzisiaj wychowanie. Integralna pedagogika przedszkolna Edmunda Bojanowskiego stanowi kontynuację, która jest poszerzona o dorobek w dziedzinie filozofii, teologii, pedagogiki i innych nauk humanistycznych i społecznych.

Współcześnie wraca się z nową dynamiką do podstaw, które od wieków kształtowały praktykę i teorię pedagogiczną w perspektywie dziejowej. Zwraca się uwagę na niezaprzeczalną rolę oraz znaczenie filozofii w rozwoju jakości myśli pedagogicznej, a także wynikających z nich działań równolegle do rozwoju koncepcji filozoficznych człowieka i jego działania w świecie. Stan współczesnej filozofii wychowania w Polsce w pełnym kontekście sięga do jej filozoficznych przedzałożeń, przyjmując wynikające $\mathrm{z}$ nich konsekwencje i perspektywy45. W tym ujęciu wychowaniu oraz kształceniu podlega cały człowiek. Nie można pedagogiki redukować do któregoś z elementów struktury bytowej osoby lub do jakiegoś aspektu jej egzystencji lub działania. Człowiek jako jedność duszy i ciała powinien być wychowywany integralnie, czyli zgodnie ze swoją ludzką naturą. Integralność wychowania oznacza tu harmonię władz, sprawności i czynów człowieka. „Pedagogika realistyczna doskonali działanie duchowych władz człowieka i utrwala jego istnieniowe $\mathrm{i}$ istotowe więzy z realnymi osobami" 46 . To pedagogika spotkania i obecności, afirmująca osobę, jej rozumność i wolność. M. Gogacz problematykę osobowych relacji wprowadza do pedagogiki, sięgając do etyki chronienia osób. Oparty na tych podstawach proces zmian adaptacyjnych i zachowania tożsamości koncepcji pedagogicznej Bojanowskiego może nadal zachować swą dynamikę i aktualność przy kontynuacji przez Służebniczki stylu dochodzenia do istoty ochrony osoby przez wychowanie.

Str e s z c z e n i e : Zakładając ochronki, E. Bojanowski tworzył i doskonalił swą koncepcję pedagogiczną. Jej filozoficzne podstawy kształtował w obrębie realizmu, który jest możliwy jedynie w kontekście zgodnego ze stanem faktycznym odczytania istniejącego świata osób oraz rzeczy. Sięgał do antropologii filozoficznej, Biblii, nauczania Kościoła, wskazując że człowiek jest jednością duszy i ciała, osobą, dzieckiem Bożym. Z tej integralnej i realistycznej koncepcji człowieka wynikała potrzeba jego integralnego rozwoju oraz wychowania. Uwzględniając dorobek myśli i praktyki pedagogicznej, kulturę, historię, tradycję Kościoła, specyfikę środowiska naturalnego, całokształt czynników oddziałujących na dziecko, jego wychowanie i organizację instytucji stworzył system wczesnej edukacji. Wierność przyjętym założeniom nadal zapewnia kontynuację, wprowadzanie

${ }^{45}$ Zob. Krasnodębski, Czlowiek, 9-28.

46 Mieczysław Gogacz, Osoba zadaniem pedagogiki. Wyklady bydgoskie (Warszawa: Oficyna Wydawnicza „Navo” 1997), 51. 
zmian adaptacyjnych z zachowaniem tożsamości koncepcji oraz rekonstrukcję jego integralnej pedagogiki w odniesieniu do realistycznej filozofii tomistycznej.

Słowa kluczowe: Edmund Bojanowski, realizm, osoba, religia, antropologia, integralne wychowanie, koncepcja pedagogiczna, tożsamość

\section{Bibliografia}

Adamek, Irena. Przygotowanie dzieci do szkoty wwarunkach rozwijającego się wychowania przedszkolnego na ziemiach polskich (druga połowa XIX wieku - 1918 rok). Kraków: Wydawnictwo Naukowe WSP, 1999.

Ajdukiewicz, Kazimierz. Zagadnienia i kierunki filozofii. Kęty: Wydawnictwo Antyk, 2004.

Archiwum Główne Służebniczek Dębickich w Dębicy (AGSD), Notatki Edmunda Bojanowskiego, (B).

Korespondencja Edmunda Bojanowskiego zlat 1853-1871, t. I, red. Leonard Smołka. Wrocław: Zgromadzenie Sióstr Służebniczek Najświętszej Maryi Panny, 2001.

Gogacz, Mieczysław. Osoba zadaniem pedagogiki. Wykłady bydgoskie. Warszawa: Oficyna Wydawnicza „Navo”, 1997.

Koźmian, Jan. Pisma. Poznań: Drukiem i nakładem Jarosława Leitgebra, 1881.

Krasnodębski, Mikołaj. Integralna antropologia wychowania. Filozofia wychowująca tomizmu konsekwentnego. Białystok: Niepaństwowa Wyższa Szkoła Pedagogiczna, 2013.

Krasnodębski, Mikołaj. Człowiek i paideia. Realistyczne podstawy filozofii wychowania. Warszawa: Wydawnictwo Szkoły Wyższej Przymierza Rodzin w Warszawie, 2009.

Krasnodębski, Mikołaj. „Antropologiczne podstawy pedagogiki integralnej”. W: Wychowanie integralne wedukacji katolickiej. Idee - twórcy - instytucje, red. Maria L. Opiela, Ewelina Świdrak, Małgorzata Łobacz, 21-43. Lublin: Wydawnictwo KUL, 2014.

Krąpiec, Mieczysław A. Człowiek i prawo naturalne. Lublin: PTTA, 2009.

Kukołowicz, Teresa. „Nowe koncepcje wychowania”. Chrześcijanin w Świecie 4 (1993): 53-58.

Mazur, Piotr S. „Mieczysława A. Krąpca OP antropologia integralna”. Czlowiek w Kulturze 19 (2007): 155-162.

Opiela, Maria. Dynamika przemian działalności opiekuńczo-wychowawczej Sióstr Stużebniczek BDNP w ochronkach. Dębica: SBDNP, 2011.

Opiela, Maria. Integralna pedagogika przedszkolna w systemie wychowania Edmunda Bojanowskiego. Kontynuacja i zmiana. Lublin: Wydawnictwo KUL, 2013.

Opiela, Maria. „Zespolenie idei narodowej, odrodzenia religijnego z pracą społeczną dla rozwoju rodzimej koncepcji wczesnej edukacji”. Polska Myśl Pedagogiczna 1 (2015): 143-160.

Palka, Stanisław. Pedagogika w stanie tworzenia. Kraków: Wydawnictwo UJ, 1999.

Powszechna encyklopedia filozofii, red. Andrzej Maryniarczyk, Wojciech Daszkiewicz, Teresa Zawojska, Agata Szymaniak, t. III i VIII. Lublin: Polskie Towarzystwo Tomasza z Akwinu, 2002, 2007.

Stępień, Tomasz. Wprowadzenie do antropologii filozoficznej św. Tomasza zAkwinu. Warszawa: Warszawskie Towarzystwo Teologiczne, 2013.

Wald, Berthold. Filozofia wstudium teologï. Przekład Joanna Jakuszko. Lublin: Polskie Towarzystwo Tomasza z Akwinu, 2006.

Woroniecki, Jacek. „Program integralnej pedagogiki katolickiej”. Ateneum Kaptańskie 47 (1947): 28-36. 